\title{
Gambaran Karies Gigi Sulung pada Anak Stunting di Indonesia
}

\author{
Novia N. Aviva, ${ }^{1}$ Damajanty H. C. Pangemanan, ${ }^{2}$ Pritartha S. Anindita ${ }^{1}$
}

\author{
${ }^{1}$ Program Studi Pendidikan Dokter Gigi Fakultas Kedokteran Universitas Sam Ratulangi \\ Manado \\ ${ }^{2}$ Bagian Fisiologi Fakultas Kedokteran Universitas Sam Ratulangi Manado \\ Email: novianuraviva@gmail.com
}

\begin{abstract}
Dental caries, as well as stunting in children, is still a worldwide problem including in Indonesia. Malnutrition can cause stunting and abnormal growth and development of teeth causing the child's teeth become more susceptible to caries. This study was aimed to obtain the description of primary dental caries among stunting children in Indonesia. This was a literature review study. Three databases used in this study, as follows: Pubmed, ClinicalKey, and Google Scholar. The keywords were stunting AND caries AND Indonesia. After being selected based on inclusion and exclusion criteria, a critical appraisal was carried out that obtained 5 literatures consisting of 4 cross-sectional studies and 1 cohort study. The results showed that stunting children had higher percentage of primary dental caries than normal children, with moderate to high caries severity reaching $80 \%$. Children who suffered from high dental caries severity had a high chance of suffering from stunting in the future. In conclusion, stunting children in Indonesia suffered from caries of primary teeth categorized as high severity caries. There was a relationship between caries of primary teeth and stunting in children.
\end{abstract}

Keywords: Primary dental caries, stunting, child.

\begin{abstract}
Abstrak: Seperti halnya karies gigi, stunting pada anak masih menjadi masalah dunia termasuk Indonesia. Kekurangan gizi pada masa-masa kritis dapat menyebabkan stunting pada anak serta tumbuh kembang gigi yang tidak normal sehingga gigi anak lebih rentan mengalami karies. Penelitian ini bertujuan untuk mengetahui gambaran karies gigi sulung pada anak stunting di Indonesia. Jenis penelitian ialah studi pustaka. Pencarian data menggunakan tiga database yaitu Pubmed, ClinicalKey, dan Google Scholar. Kata kunci yang digunakan yaitu stunting AND caries AND Indonesia. Setelah diseleksi berdasarkan kriteria inklusi dan ekslusi, dilakukan critical appraisal dan didapatkan 5 literatur terdiri dari 4 cross-sectional study dan 1 cohort study. Hasil penelitian menunjukkan anak stunting memiliki pengalaman karies gigi sulung lebih tinggi daripada anak normal dengan tingkat keparahan karies sedang sampai tinggi mencapai $80 \%$. Anak yang menderita pengalaman karies gigi sulung parah, memiliki peluang tinggi menderita stunting di kemudian hari. Simpulan penelitian ini ialah anak stunting di Indonesia memiliki pengalaman karies pada gigi sulung dan terbanyak pada tingkat keparahan karies yang tinggi. Terdapat hubungan antara karies pada gigi sulung dan stunting pada anak.
\end{abstract}

Kata kunci: karies gigi sulung, stunting, anak.

\section{PENDAHULUAN}

Kesehatan gigi dan mulut merupakan bagian penting dari kesehatan tubuh yang saling berkaitan satu sama lain. Masalah gigi dan mulut yang paling banyak terjadi di seluruh dunia, baik di negara maju maupun berkembang yakni karies gigi.
Karies gigi merupakan penyakit tidak menular yang dijumpai pada segala usia terutama pada anak-anak. Hasil Riset Kesehatan Dasar (Riskesdas) tahun 2018 menunjukkan prevalensi anak di Indonesia yang mengalami karies pada gigi sulung sebesar 90,2\%. Indeks def-t yaitu salah satu 
indeks yang digunakan untuk mengukur tingkat karies gigi sulung menunjukkan skor rerata def-t anak usia 5 tahun sebesar 8,3 pada anak laki-laki sedangkan pada anak perempuan 8,0 yang berarti setiap anak memiliki sekitar 8 gigi sulung yang mengalami karies. ${ }^{1}$

Karies gigi sulung juga berpengaruh terhadap kesehatan tubuh anak secara umum khususnya gangguan fungsi pengunyahan yang menyebabkan terganggunya penyerapan dan pencernaan makanan. Oleh karena itu, karies gigi pada akhirnya dapat mengganggu gizi anak sehingga menyebabkan terjadinya malnutrisi. Keadaan malnutrisi yang berlangsung lama atau kronis menyebabkan anak menjadi stunting, yaitu kondisi terhambatnya pertumbuhan akibat kekurangan gizi bersifat kronis sehingga anak terlalu pendek untuk usianya. ${ }^{2}$

Seperti halnya karies gigi, stunting pada anak masih menjadi masalah yang dihadapi dunia termasuk Indonesia. Stunting terjadi karena terhambatnya pertumbuhan akibat kekurangan gizi bersifat kronis dari keadaan yang berlangsung lama seperti perilaku hidup tidak sehat dan pola makan yang kurang baik sejak anak dilahirkan, terlebih pada 1000 HPK (hari pertama kehidupan). ${ }^{2}$

Stunting dapat menyebabkan masalah baru seperti pendek lintas generasi, terhambatnya perkembangan kognitif anak, dan lebih rentan terhadap infeksi serta penyakit tidak menular. ${ }^{3}$ Menurut data prevalensi stunting yang dikumpulkan World Health Organization (WHO), Indonesia termasuk negara dengan prevalensi tertinggi ketiga di Regional Asia Tenggara. ${ }^{4}$ Hasil Riskesdas tahun 2018 menunjukkan prevalensi stunting di Indonesia berada di angka 30,8\%, masih jauh mencapai level yang direkomendasikan WHO yakni sebesar $20 \%{ }^{1}$

Telah diketahui bahwa 1000 HPK terdiri dari 270 hari masa kehamilan ibu ditambah 730 hari setelah anak lahir, menjadi masa yang penting karena sangat berpengaruh terhadap kesehatan tubuh anak secara umum maupun kesehatan rongga mulut. ${ }^{2}$ Kekurangan gizi pada masa-masa kritis ini dapat menyebabkan stunting pada anak serta tumbuh kembang gigi yang tidak normal sehingga gigi anak lebih rentan mengalami karies. ${ }^{5,6}$ Anak yang lahir normal dengan gizi baik pun tidak lepas dari risiko stunting karena asupan gizi anak yang kurang dan tidak sesuai dengan kebutuhan gizi dalam waktu lama atau kronis dapat menyebabkan stunting pada anak. ${ }^{7}$ Kondisi kekurangan gizi kronis ini juga berpengaruh terhadap kesehatan gigi dan mulut seperti dapat menyebabkan gangguan perkembangan kelenjar saliva yang dapat meningkatkan risiko terjadinya karies gigi. ${ }^{8}$

Sejalan dengan penelitian Rahman ${ }^{9}$ di Kabupaten Banjar yang menyatakan indeks def-t pada anak stunting lebih tinggi secara bermakna daripada anak tidak stunting. Menurut penelitian longitudinal DelgadoAngulo di Peru, anak stunting mengalami kenaikan jumlah karies yang tinggi dibandingkan anak tidak stunting setelah follow up selama tiga setengah tahun. ${ }^{8}$ Dengan demikian karies gigi sulung pada anak stunting dapat menjadi masalah yang lebih serius dibandingkan anak tidak stunting. Berdasarkan latar belakang tersebut, penulis tertarik untuk membahas dan menelaah berbagai informasi ilmiah mengenai gambaran karies gigi sulung pada anak stunting di Indonesia.

\section{METODE PENELITIAN}

Penelitian ini dilakukan pada bulan MeiJuli 2020. Jenis penelitian ialah studi pustaka. Data penelitian ialah data sekunder yang diperoleh dari tiga database dengan kriteria yang ditentukan yaitu Pubmed, ClinicalKey, dan Google Scholar. Kata kunci yang digunakan dalam pencarian artikel yaitu stunting AND caries AND Indonesia. Kriteria inklusi dalam penelitian ini yakni: populasi anak stunting, outcomes karies pada gigi sulung, jenis penelitian cohort study, cross-sectional study, atau case control study, tahun publikasi 2011 sampai 2020 serta berbahasa Inggris dan Indonesia. Kriteria ekslusi yakni populasi selain anak di Indonesia dan artikel tidak tersedia fulltext.

Berdasarkan hasil pencarian pustaka, didapatkan sebanyak 52 artikel menggunakan PubMed, 35 menggunakan ClinicalKey, dan 1070 menggunakan Google Scholar 
( $\mathrm{n}=1157)$ yang sesuai dengan kata kunci tersebut. Hasil pencarian kemudian dilakukan skrining berdasarkan judul yang sesuai dengan tema studi pustaka didapatkan 30 artikel $(n=30)$. Selanjutnya 30 artikel diskrining abstrak dan fulltext berdasarkan kriteria inklusi dan ekslusi sehingga didapatkan 5 artikel $(\mathrm{n}=5)$. Critical appraisal dilakukan pada 5 artikel yang memenuhi kriteria kelayakan dan yang digunakan dalam studi pustaka. Analisis kualitas metode penelitian dalam setiap artikel menggunakan The Joanna Briggs Institute (JBI) Critical
Appraisal baik untuk jenis studi cohort maupun cross-sectional. Hasil telaah ini diaudit oleh pakar yang memahami topik yang diteliti dalam studi pustaka.

\section{HASIL PENELITIAN}

Setelah melalui tahap seleksi studi, didapatkan lima artikel yang memenuhi kriteria inklusi dan ekslusi terdiri dari empat penelitian cross-sectional dan satu penelitian cohort. Tabel 1 menampilkan karakteristik kelima artikel yang dipergunakan dalam studi ini.

Tabel 1. Hasil pencarian pustaka

\begin{tabular}{|c|c|c|c|c|c|}
\hline No. & Peneliti dan judul & $\begin{array}{l}\text { Lokasi } \\
\text { penelitian }\end{array}$ & $\begin{array}{l}\text { Jenis } \\
\text { penelitian }\end{array}$ & $\begin{array}{l}\text { Jumlah } \\
\text { sampel }\end{array}$ & Hasil penelitian \\
\hline 1. & $\begin{array}{l}\text { Simorangkir et al. }{ }^{10} \\
\text { (2018) } \\
\text { Relationship between } \\
\text { caries experience and } \\
\text { food intake with stun- } \\
\text { ting among 6-8 years } \\
\text { old of elementary } \\
\text { school at Pantai Labu } \\
\text { District in 2018. }\end{array}$ & $\begin{array}{l}\text { Deli } \\
\text { Serdang, } \\
\text { Indonesia }\end{array}$ & $\begin{array}{l}\text { Cross- } \\
\text { sectional } \\
\text { study }\end{array}$ & $\begin{array}{l}82 \text { anak nor- } \\
\text { mal dan } 62 \\
\text { anak stunting } \\
\text { usia 6-8 tahun. }\end{array}$ & $\begin{array}{l}87 \% \text { anak stunting mengalami } \\
\text { karies tinggi. Uji statistik Chi } \\
\text { Square menunjukkan adanya } \\
\text { hubungan signifikan antara } \\
\text { pengalaman karies dan stunting } \\
\text { pada anak dengan hasil } p=0,004 \text {. } \\
\text { PR }=2,15>1 \text { dengan skor CI } \\
1,2616-3,799 \text { yang berarti anak } \\
\text { dengan pengalaman karies tinggi } \\
2,15 \text { kali lebih mungkin menjadi } \\
\text { stunting dibanding anak dengan } \\
\text { pengalaman karies rendah. }\end{array}$ \\
\hline 2. & $\begin{array}{l}\text { Rahman et al. }{ }^{9} \text { (2016) } \\
\text { Hubungan antara sta- } \\
\text { tus gizi pendek (stun- } \\
\text { ting) dengan tingkat } \\
\text { karies gigi. }\end{array}$ & $\begin{array}{l}\text { Banjar, } \\
\text { Indonesia }\end{array}$ & $\begin{array}{l}\text { Cross- } \\
\text { sectional } \\
\text { study }\end{array}$ & $\begin{array}{l}30 \text { anak nor- } \\
\text { mal dan } 30 \\
\text { anak stunting } \\
\text { usia } 4-5 \text { tahun. }\end{array}$ & $\begin{array}{l}\text { Indeks def-t anak stunting } 8,23 \\
\text { anak normal 3,3. Uji Chi Square } \\
\text { menghasilkan } p=0,000(p<0,05) \\
\text { yang berarti terdapat perbedaan } \\
\text { signifikan antara indeks def-t } \\
\text { anak stunting dan normal. }\end{array}$ \\
\hline 3. & $\begin{array}{l}\text { Dimaisib-Nabuab et } \\
\text { al. }{ }^{11} \text { (2018) } \\
\text { Nutritional status, den- } \\
\text { tal caries and tooth } \\
\text { eruption in children: a } \\
\text { longitudinal study in } \\
\text { Cambodia, Indonesia, } \\
\text { and Lao PDR }\end{array}$ & Indonesia & $\begin{array}{l}\text { Cohort } \\
\text { study }\end{array}$ & $\begin{array}{l}570 \text { (86 stun- } \\
\text { ting) anak usia } \\
6-7 \text { tahun, se- } \\
\text { telah } 2 \text { tahun } \\
\text { di follow-up } \\
\text { tersisa } 486 \text { ( } 79 \\
\text { stunting) anak } \\
\text { usia 8-9 tahun. }\end{array}$ & $\begin{array}{l}\text { Pada usia 6-7 tahun skor pufa } \\
\text { anak stunting sebesar } 4,1 \pm 3,6 \\
\text { dan anak normal } 3,0 \pm 3,0 \text {. skor } \\
\text { dt pada anak stunting } 9,6 \pm 4,6 \\
\text { dan anak normal } 7,9 \pm 4,4 \text {. } \\
\text { Anak yang memiliki dt lebih } \\
\text { tinggi pada usia 6-7 tahun } \\
\text { memiliki peluang tinggi menjadi } \\
\text { stunting di usia } 8-9 \text { tahun. Uji } \\
\text { Mann Whitney } U-\text { Test mendapat- } \\
\text { kan nilai } p=0,002 \text {. }\end{array}$ \\
\hline 4. & $\begin{array}{l}\text { Nabila et al. }{ }^{12} \text { (2019) } \\
\text { Hubungan stunting } \\
\text { (status gizi pendek) dan } \\
\text { pengalaman karies } \\
\text { (dmfs) pada anak di } \\
\text { Kecamatan Babalan } \\
\text { Kabupaten Langkat }\end{array}$ & $\begin{array}{l}\text { Langkat, } \\
\text { Indonesia }\end{array}$ & $\begin{array}{l}\text { Cross- } \\
\text { sectional } \\
\text { study }\end{array}$ & $\begin{array}{l}105 \text { anak nor- } \\
\text { mal dan } 30 \\
\text { anak stunting } \\
\text { usia } 3-5 \text { tahun. }\end{array}$ & $\begin{array}{l}\text { Skor dmfs rata-rata pada anak } \\
\text { normal } 7,47 \pm 3,74 \text { dan anak } \\
\text { stunting yaitu } 14,03 \pm 6,16 \text {. } \\
\text { Hasil uji T-Test Independent } \\
\text { menunjukkan nilai } p=0,0001 \\
\text { ( } p<0,05) \text { yang berarti terdapat hu- } \\
\text { bungan signifikan antara stunting } \\
\text { dan pengalaman karies anak. }\end{array}$ \\
\hline
\end{tabular}




\begin{tabular}{|c|c|c|c|c|c|}
\hline 5. & $\begin{array}{l}\text { Ningtias et al. }{ }^{13}(2019) \\
\text { Hubungan stunting dan } \\
\text { pengetahuan ibu terha- } \\
\text { dap karies pada balita } \\
\text { di Desa Dukuhmaja } \\
\text { Kecamatan Songgom } \\
\text { Kabupaten Brebes. }\end{array}$ & $\begin{array}{l}\text { Brebes, } \\
\text { Indonesia }\end{array}$ & $\begin{array}{l}\text { Cross- } \\
\text { sectional } \\
\text { study }\end{array}$ & $\begin{array}{l}32 \text { anak stun- } \\
\text { ting usia } 2-5 \\
\text { tahun. }\end{array}$ & $\begin{array}{l}26 \text { anak stunting yang memiliki } \\
\text { karies sedang sampai tinggi } \\
(81,25 \%) \text {. Uji Spearman menun- } \\
\text { jukkan nilai } p=0,012 \quad(p<0,05) \\
\text { yang berarti bahwa terdapat } \\
\text { hubungan bermakna antara } \\
\text { stunting terhadap karies pada } \\
\text { anak, serta hubungan pengeta- } \\
\text { huan ibu terhadap karies pada } \\
\text { anak }(p=0,003) \text {. }\end{array}$ \\
\hline
\end{tabular}

\section{BAHASAN}

Hasil penelitian dari pustaka yang ditelaah menunjukkan bahwa tingkat karies gigi sulung lebih tinggi pada anak stunting dibandingkan anak normal. Penelitian oleh Rahman et $\mathrm{al}^{9}$ di Kabupaten Banjar mendapatkan rerata skor deft anak stunting yaitu 8,23 , hampir tiga kali lipat lebih tinggi dari kelompok anak normal dengan rerata 3,3. Sejalan dengan penelitian Nabila dan Pintauli $^{12}$ di Kabupaten Langkat yang melaporkan bahwa rerata skor deft anak stunting $14,03 \pm 6,16$, dua kali lipat lebih tinggi daripada kelompok anak normal yaitu $7,47 \pm 3,74$. Penelitian Dimaisib-Nabuab et $\mathrm{al}^{11}$ juga mendapatkan bahwa skor pufa dan $\mathrm{dt}$ rerata anak stunting lebih tinggi secara bermakna dibandingkan anak normal di Indonesia pada usia 6-7 tahun yakni dt rerata $9,6 \pm 4,6$ pada anak stunting dan 7,9 $\pm 4,4$ pada anak normal, serta pufa rerata anak stunting

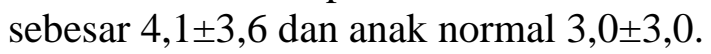

Anak stunting yang menderita karies gigi sulung, dengan rerata tingkat keparahan karies sedang sampai tinggi, dan sedikit yang rendah. Berdasarkan hasil penelitian Simorangkir et al ${ }^{10}$ di Kabupaten Deli Serdang, terdapat sebanyak $87 \%$ anak stunting memiliki karies tinggi dan 13\% yang memiliki karies rendah, serta penelitian Ningtias et $\mathrm{al}^{13}$ di Kabupaten Brebes yang mendapatkan $81,25 \%$ anak stunting memiliki karies sedang sampai tinggi dan $18,75 \%$ yang memiliki karies rendah. Hal ini terjadi karena malnutrisi dikorelasikan sebagai faktor host yang dikaitkan dengan perkembangan lesi karies, terutama kelainan struktur gigi dan kelenjar saliva. Kelainan struktur gigi yaitu hipoplasia berpotensi membuat suasana rongga mulut menjadi kario- genik akibat meningkatnya proses demineralisasi dari enamel protektif yang tipis. ${ }^{14}$

Karies pada anak stunting cenderung lebih parah karena perkembangan kelenjar saliva yang mengalami atrofi sehingga fungsi buffer dan self-cleansing berkurang. Laju aliran saliva memiliki hubungan secara langsung dengan terjadinya karies melalui oral clearance yang membantu menyingkirkan patogen (virus, bakteria, jamur) dari gigi dan permukaan mukosa. Buffer berfungsi menetralisir $\mathrm{pH}$ setelah makan dan meminimalkan waktu untuk terjadinya demineralisasi. Di bawah $\mathrm{pH}$ kritis, materi anorganik gigi akan terlarut. Kurangnya protein dan defisiensi mikronutrien seperti vitamin, zink, dan zat besi, dapat memengaruhi jumlah dan komposisi saliva sehingga menyebabkan keterbatasan efek protektif saliva. ${ }^{8,15}$

Anak yang memiliki pengalaman karies tinggi juga berisiko menderita stunting. Berdasarkan hasil penelitian Simorangkir et $\mathrm{al}^{10}$ di Kabupaten Deli Serdang diperoleh $\mathrm{PR}=2,15>1$ dengan skor CI 1,2616-3,799 yang berarti anak dengan pengalaman karies tinggi 2,15 kali lebih mungkin menjadi stunting dibanding anak dengan pengalaman karies rendah. Sejalan dengan penelitian longitudinal Dimaisip-Nabuab et $\mathrm{al}^{11} \mathrm{di}$ Indonesia yang menyebutkan bahwa anak yang memiliki dt lebih tinggi pada usia 6-7 tahun memiliki peluang tinggi menjadi stunting di usia 8-9 tahun. Hal ini dapat disebabkan karena menderita karies gigi merupakan faktor penyebab stunting yang dikaitkan dengan kejadian infeksi pada anak. Kejadian infeksi dapat menyebabkan penurunan nafsu makan, penurunan absorbsi, yang berakibat lanjut penurunan mikro- 
nutrien dalam tubuh. Menderita karies gigi dalam waktu lama menjadi variabel penyebab terganggunya fungsi pengunyahan yang berakibat memengaruhi nafsu makan serta gangguan pencernaan dan intake gizi sehingga berdampak terhadap gangguan pertumbuhan hingga memengaruhi status gizi anak. Oleh karena itu, anak dengan pengalaman karies tinggi lebih berisiko menderita stunting di kemudian hari dibanding anak normal. ${ }^{16,17}$

Hasil penelitian dalam pustaka yang telah dipaparkan menunjukkan bahwa terdapat hubungan antara karies gigi sulung dan stunting pada anak. Hal ini sesuai dengan faktor utama penyebab stunting pada anak yang dikaitkan dengan 1000 HPK bahwa malnutrisi pada ibu dan malnutrisi pada anak sebelum usia 2 tahun menyebabkan anak menjadi stunting. Defisiensi nutrisi pada masa ini juga mengganggu pertumbuhan dan perkembangan struktur gigi sulung. Oleh karena itu, tingkat karies gigi sulung pada anak stunting menjadi lebih tinggi daripada anak normal. ${ }^{17}$

Hasil penelitian Oktarina dan Sudiarti ${ }^{18}$ di Sumatera menunjukkan bahwa balita yang ibunya memiliki tinggi badan pendek, tingkat asupan lemak rendah, jumlah anggota keluarga banyak, dan memiliki sumber air minum yang tidak terlindung berisiko mengalami stunting berturut-turut 1,36, 1,30, 1.38, dan 1,36 kali dibandingkan kelompok pembandingnya $(p<0,05)$. Penelitian lainnya oleh Aryastami et $\mathrm{al}^{19}$ di Indonesia menyebutkan kondisi ibu pada saat kehamilan yang mengalami malnutrisi, kekurangan energi kronis (KEK), atau anemia, berisiko melahirkan bayi dengan berat badan lahir rendah (BBLR). Bayi BBLR terkait dengan mortalitas, mobilitas janin, neonatal, gangguan pertumbuhan, gangguan perkembangan kognitif, dan penyakit kronis di masa mendatang. Kejadian BBLR memengaruhi sekitar 20\% dari terjadinya stunting. ${ }^{19}$

Kondisi gizi ibu saat kehamilan juga kaitkan dengan kejadian karies gigi pada anak. Hal ini disebabkan karena gigi sulung mulai terbentuk pada minggu ke-4 periode pertumbuhan janin, dan proses mineralisasi dimulai selama minggu ke-12. Hal ini merupakan fase kritis karena proses aposisi matriks yang membangun struktur jaringan keras gigi sulung terjadi. Selain kekurangan makronutrien, mikronutrien juga berperan penting. Vitamin A penting untuk integritas dan diferensiasi epitel. Defisiensi vitamin A dapat memengaruhi aktivitas sel ameloblas dalam membentuk enamel gigi. Vitamin D juga diperlukan dalam metabolisme kalsium dan fosfor, yang penting untuk pertumbuhan gigi dan tulang. Zat gizi mikro lain yang penting dalam perkembangan struktur enamel gigi ialah kalsium, fosfor, dan magnesium. ${ }^{20}$ Sejalan dengan hasil penelitian Tanaka et $\mathrm{al}^{21}$ di Jepang yang melaporkan hubungan antara asupan vitamin D ibu yang lebih tinggi selama kehamilan dan pengurangan risiko karies gigi pada anak. Penelitian oleh Badruddin et $\mathrm{al}^{22}$ di Kota Depok menunjukkan terdapat hubungan bermakna antara status gizi ibu saat kehamilan dengan karies gigi sulung pada anak $(\mathrm{p}<0,001)$. Oleh karena itu, malnutrisi termasuk defisiensi makronutrien dan mikronutrien pada ibu hamil akan memengaruhi integritas gigi sulung anak kelak.

\section{SIMPULAN}

Anak stunting di Indonesia memiliki pengalaman karies pada gigi sulung dan terbanyak pada tingkat keparahan karies yang tinggi. Karies pada gigi sulung dan stunting pada anak memiliki hubungan yang saling memengaruhi satu sama lain.

\section{Konflik Kepentingan}

Penulis menyatakan tidak terdapat konflik kepentingan dalam studi ini.

\section{DAFTAR PUSTAKA}

1. Badan Penelitian dan Pengembangan Kesehatan. Hasil utama Riskesdas 2018. Jakarta: Kemenkes RI, 2018; p.203-6, 558-79.

2. Utomo BS. Bersama Cegah Stunting. Warta Kesmas (2nd ed): Cegah Stunting itu Penting. Jakarta: Kementrian Kesehatan RI, 2018; p. 6-7.

3. Trihono, Atmarita, Tjandrarini DH, Irawati A, Utami NH, Tejayanti T, et al. Pendek (Stunting) di Indonesia, Masalah dan 
Solusinya. Jakarta: Badan Penelitian dan Pengembangan Kesehatan; 2015. h.82-97.

4. Buletin Jendela: Situasi Balita Pendek (Stunting) di Indonesia. Jakarta: Pusat Data \& Informasi Kementerian Kesehatan RI, 2018; p.1-2.

5. Nasution MI. Morfologi Gigi Desidui dan Gigi Permanen. Medan: USU Press, 2008; p. 111.

6. Fajriani, Handayani H. Penatalaksanaan early childhood caries. J Dentofasial. 2011; 10(3):181-2.

7. Anugeraheni HS, Kartasurya MI. Faktor risiko kejadian stunting pada anak usia 12-36 bulan di Kecamatan Pati Kabupaten Pati. J Nutr College 2012;1(1):30-7.

8. Delgado-Angulo EK, Hobdell MH, Bernabe E. Childhood stunting and caries increment in permanent teeth: a three and a half year longitudinal study in Peru. Int $\mathrm{J}$ Paediatr Dent 2013;23(2):101-9.

9. Rahman T, Adhani R, Triawanti. Hubungan antara status gizi pendek (stunting) dengan tingkat karies gigi. J Dentino. 2016;1(1): 88-93.

10. Simorangkir EA, Pintauli S, Sudaryati E. Relationship between caries experience and food intake with stunting among 68 years old of elementary school at Pantai Labu District in 2018. J Britain International of Exact Sciences 2020; 2(1):313-9.

11. Dimaisib-Nabuab J, Duijster D, Benzian H, Heinrich-Weltzien R, Homsavath A, Monse B, et al. Nutritional status, dental caries, and tooth eruption in children: a longitudinal study in Cambodia, Indo nesia, and Lao PDR. BMC Pediatrics. 2018; 18(1):300.

12. Nabila, Pintauli S. Hubungan stunting (status gizi pendek) dan pengalaman karies (dmfs) pada anak di Desa Babalan Kabupaten Langkat [Electronic Skrip si]. Medan: Universitas Sumatera Utara; 2019.

13. Ningtias PA, Sadimin, Mardiati E. Hubungan stunting dan pengetahuan ibu terhadap karies pada balita di Desa Dukuhmaja Kecamatan Songgom Kabupaten Bre bes [Electronic Skripsi]. Semarang: Poltekkes Kemenkes; 2019.

14. Sheetal A, Hiremath VK, Patil AG, Sajjansetty S, Kumar S. Malnutrition and its oral outcome a review. JCDR. 2013; 7(1): 178-80.

15. Psoter WJ, Spielman AL, Gebrian B, St Jean R, Katz RV. Effect of childhood malnutrition on salivary flow and $\mathrm{pH}$. Arch Oral Biol 2009;53:231-7.

16. Abdat M. Stunting pada balita dipengaruhi kesehatan gigi geliginya. J Syiah Kuala Dent Soc. 2019;4(2):33-8.

17. Achmad H, Ramadany S, Fajriani, Sukmana BI, Hanan N, Hartami E, et al. A review of stunting growth in children: relationship to the incidence of dental caries and its handling in children. J Sys Rev Pharm. 2020;11(6):230-5.

18. Oktarina Z, Sudiarti T. Faktor risiko stunting pada balita (24-59 bulan) di Sumatera. J Gizi dan Pangan. 2013;8(3):175-80.

19. Aryastami NK, Shankar A, Kusumawardani N, Besral B, Jahari AB, Achadi E. Low birth weight was the most dominant predictor associated with stunting among children aged 12-23 months in Indonesia. BMC Nutrition. 2017;3(16): 1-6.

20. Kumar GS. Orban's Oral Histology and Embryology (14 « ed). London: Elsevier, 2015; p. 23.

21. Tanaka K, Hitsumoto S, Miyake Y, Okubo H, Sasaki S, Miyatake N, et al. Higher vitamin $\mathrm{D}$ intake during pregnancy is associated with reduced risk of dental caries in young Japanese children. J Annals of Epidemiology. 2015;23(8): 620-5.

22. Badruddin IA, Khansa M, Darwita RR, Rahardjo A. The relation of mother nutritional status to primary teeth dental caries. Int J App Pharm. 2017;9(2):142-3. 